\title{
LISTY PASTERSKIE, OKÓLNIKI I INNE PISMA REKTORA POLSKIEJ MISJI KATOLICKIEJ, KS. LEONA ŁAGODY, W ZBIORACH ARCHIWUM PMK W PARYŻU
}

\begin{abstract}
Najstarszą z Polskich Misji Katolickich jest Polska Misja Katolicka we Francji, sięgająca korzeniami przełomu wieków XVIII i XIX, a powołana oficjalnie z dniem 17 lutego 1836 r. Misja dysponuje własnym Archiwum, które ma na celu zachowanie świadectw działalności Misji oraz rozmaitych stowarzyszeń polonijnych działających na terenie Francji. Jednym z działów w zasobie tego Archiwum jest zbiór listów pasterskich i okólników wchodzący w skład akt tworzących dokumenty powiązane z działalnością Rektoratu Misji. Analiza zawartości tego zbioru, odnoszącego się głównie do lat 1929-1933, rzuca światło na aktywność duszpasterską i organizacyjną władz Polskiej Misji Katolickiej we Francji.
\end{abstract}

\section{LISTY PASTERSKIE REKTORA PMK, KS. LEONA ŁAGODY, Z LAT 1929-1933}

W świetle ustawodawstwa kościelnego rektor misji katolickiej był oficjalnie jedynie delegatem prymasa Polski i wikariuszem współpracownikiem proboszcza paryskiej parafii św. Magdaleny ${ }^{1}$. W praktyce jednak jego działalność porównać można do działalności biskupa diecezjalnego, przy czym jego „diecezją” był teren całej Francji, na którym znajdowały się liczne placówki polskiego duszpasterstwa emigracyjnego. Rektor PMK był jedynym przedstawicielem episkopatu polskiego wobec francuskiego, wyznaczał placówki przysłanym przez prymasa Polski kapłanom i zawierał umowy z ordynariuszami francuskimi, którzy tych kapłanów przyjmowali do polskojęzycznego duszpasterstwa, tworzył nowe placówki duszpaster-

Ks. dr hab. SŁAwomiR ZYCH - adiunkt Ośrodka Badań nad Polonią i Duszpasterstwem Polonijnym, Instytut Historii na Katolickim Uniwersytecie Lubelskim Jana Pawła II; e-mail: szych@kul.pl. ORCID: https://orcid.org/0000-0002-1518-9622.

${ }^{1}$ R. Dzwonkowski, Polska opieka religijna we Francji 1909-1939, Poznań-Warszawa 1988, s. 64. 
skie i koordynował pracę powierzonych sobie kapłanów ${ }^{2}$. Głównym jego zadaniem było jednak podtrzymywanie życia religijnego polskich emigrantów oraz ich więzi z ojczyzną, jej kulturą, zwyczajami, językiem³ ${ }^{3}$.

Specyficzną formą duszpasterskiej troski rektora PMK o powierzonych sobie wiernych, było kierowanie doń listów, które określić można mianem listów pasterskich. Praktykę ich pisania zapoczątkowali już apostołowie, zaś w czasach po Soborze Trydenckim stało się to powinnością każdego biskupa diecezjalnego. Listy zawierały szczegółowe omówienie niektórych zasad wiary, obyczajów, zagadnień teologicznych lub duszpasterskich w aspekcie konkretnych okoliczności i potrzeb. Informowały o ważnych rocznicach i wydarzeniach ${ }^{4}$.

Zbiór listów ks. Leona Łagody ${ }^{5}$ zachowanych w Archiwum PMK otwiera list datowany na dzień 8 maja 1929 r., a odczytany wiernym w uroczystość Zesłania Ducha Świętego. Ten siedmiostronicowy tekst był jednocześnie formą przywitania się nowego rektora z powierzonym jego pieczy ludem i inauguracją jego duszpasterskiej działalności. Ksiądz Łagoda, nawiązując do kolejnych darów Ducha Świętego, zwracał się najpierw do mężów i ojców realizujących nie tylko trudne zadanie zabezpieczenia warunków godziwej egzystencji swoich rodzin, ale też odpowiedzialny obowiązek obrony wiary i narodowego zwyczaju z dala od ojczyzny. Wszystkim żonom i matkom polecał rektor PMK troskę o wychowanie dzieci w duchu umiłowania ojczyzny i wiary katolickiej. Witając się z młodzieżą, ks. Łagoda zwracał uwagę na czystość i godność panieńską, zaś dzieci zachęcał do nauki języka ojczystego ${ }^{6}$.

2 M. Brudzisz, Archiwum Polskiej Misji Katolickiej we Francji, Kraków-Lublin 2015, s. 36.

3 Tamże, s. 39.

4 J. DuchniewsKi, Listy pasterskie, w: Encyklopedia Katolicka, t. X, Lublin 2004, kol. 1161-1165.

${ }^{5}$ Leon Łagoda (1894-1942) - kapłan archidiecezji gnieźnieńskiej. Wyświęcony na kapłana 3 września 1916 r. przez bpa Wilhelma Atanazego Kloskego. Studia filozoficzno-teologiczne odbył w Gnieźnie i Poznaniu oraz po święceniach kapłańskich - w Monasterze. Od 1918 r. wikariusz w Grabowie i dyrektor Gimnazjum i Szkoły Realnej w Gnieźnie. Od 1925 r. prokurator fiskalny przy Arcybiskupim Sądzie Duchownym w Gnieźnie. Od 1926 r. dyrektor Miejskiego Gimnazjum Żeńskiego im. bł. Jolanty w Gnieźnie oraz wykładowca teologii moralnej i prawa kanonicznego w gnieźnieńskim seminarium. Od 1927 r. prokurator w tymże seminarium i lektor języków starożytnych (łacina i greka) W 1929 r. zwolniony z funkcji wizytatora diecezjalnego nauki religii w szkołach archidiecezji gnieźnieńskiej. W 1923 r. mianowany kanonikiem kolegiaty św. Jerzego, zaś w 1931 - Tajnym Szambelanem Jego Świątobliwości. Od 1929 do 1933 r. rektor PMK we Francji. Od 1934 r. proboszcz w parafii w Miłosławiu, od 1938 - dziekan miłosławski. W 1941 r. został aresztowany przez Niemców i osadzony w Forcie VII w Poznaniu, potem w obozie koncentracyjnym w Dachau, gdzie zmarł. J. SzYMAŃsKi, Duszpasterze Polonii i Polaków za granica. Słownik biograficzny, t. II, Lublin 2011, s. 116.

${ }^{6}$ Archiwum Polskiej Misji Katolickiej we Francji [dalej: APMKF], R.II. 4.1. „Okólniki”, List rektora PMK ks. Leona Łagody do Rodaków z dnia 8 maja 1929 r., mps. 
Kolejny zachowany w zbiorach archiwum PMK w Paryżu list ks. Łagody adresowany jest do młodzieży, a okolicznością, która skłoniła rektora do jego wystosowania, było święto patrona młodzieży św. Stanisława Kostki. List ten nie został datowany. Dopisek na pierwszej stronie pisma podaje rok 1929, zaś analiza następnego tekstu skierowanego do rodziców pozwala na przypuszczenie, że siedmiostronicowy tekst powstał w październiku tegoż roku. W liście odnaleźć można nawiązania do biografii świętego i polskich tradycji związanych ze wspomnieniem św. Stanisława Kostki. Autor listu zachęcał także młodych emigrantów polskich do wstępowania w szeregi młodzieżowych stowarzyszeń katolickich, które kształtować miały młodych ludzi w duchu chrześcijańskich wartości na „Chrystusowych rycerzy"'.

Następnym pismem w omawianym zbiorze jest trzystronicowy tekst zatytułowany Słowo do rodziców z okazji zbliżajacej się uroczystości świętego Stanisława Kostki. Ksiądz Łagoda podniósł w nim konieczność troski o katolickie wychowanie młodzieży przede wszystkim w domu rodzinnym. Poprosił również o zachęcanie młodzieży do wstępowania w szeregi członków młodzieżowych organizacji katolickich ${ }^{8}$.

Na dzień Matki Boskiej Częstochowskiej (26 sierpnia) 1930 r. datowany jest List do Rodaków, wystosowany po Krajowym Kongresie Eucharystycznym, który odbył się w Poznaniu w dniach 26-29 czerwca 1930 r. W pięciostronicowym piśmie wspomniane zostały duchowe owoce tego pierwszego w dziejach odrodzonej Polski zgromadzenia polskich katolików. Autor listu zwrócił też uwagę na inicjatywy związane z polską emigracją, przede wszystkim sprawy wykształcenia odpowiedniej liczby kleru dla duszpasterstwa emigracyjnego i budowy nowego gmachu seminaryjnego dla tegoż duszpasterstwa. Podniesiona została rola prymasa Polski kardynała Hlonda, który był inicjatorem tych działań. Rektor PMK w Paryżu zachęcał wiernych do modlitwy za osobę prymasa z racji jubileuszu 25-lecia jego kapłaństwa. Zwracając uwagę na potrzeby duchowe wiernych w licznych francuskich ośrodkach polskiej emigracji, ks. Łagoda prosił o materialne wsparcie dzieła budowy wspomnianego seminarium ${ }^{9}$.

Kolejny list także adresowany jest do rodaków, a dotyczy rekolekcji kapłańskich. Pismo nie zostało datowane, jednak lektura trzystronicowego tekstu pozwala na stwierdzenie, że powstał on przed 17 listopada 1930 r. Właśnie od 17 do 22 li-

7 APMKF, R.II. 4.1. „Okólniki”, List rektora PMK ks. Leona Łagody do młodzieży z 1929 na uroczystość św. Stanisława Kostki, mps.

8 APMKF, R.II. 4.1. „Okólniki”, Słowo do Rodziców z okazji zbliżającej się uroczystości świętego Stanisława Kostki, październik 1929 r., mps.

9 APMKF, R.II. 4.1. „Okólniki”, List rektora PMK ks. Leona Łagody do Rodaków, Paryż, w dniu Matki Boskiej Częstochowskiej 1930, mps. 
stopada w domu rekolekcyjnym ks. jezuitów w Clamart pod Paryżem odbywać się miały rekolekcje kapłańskie połączone ze zjazdem duchowieństwa polskiego we Francji. Autor listu zwracał się do wiernych z prośbą o modlitwę za kapłanów i dobre owoce przeżywanych ćwiczeń duchowych ${ }^{10}$.

40. rocznica ogłoszenia encykliki papieża Leona XIII Rerum Novarum stała się okazją do wystosowania kolejnego listu rektora PMK w Paryżu do rodaków. Także ten tekst pozbawiony jest datacji, znając jednak datę ogłoszenia encykliki, można przypuszczać, że list wydany został przed 15 maja 1931 r. Ksiądz Łagoda wspomina w nim wielkość myśli papieża Leona dotyczącej kwestii robotniczej i podającej środki na jej rozwiązanie ${ }^{11}$.

Kwestii robotniczych dotyczył także kolejny list. Rektor polecał, aby odczytano go w dniu 4 października 1931 r. Tekst odnosił się do spraw związanych z bezrobociem. Autor nawiązał tu do mowy wygłoszonej przez Piusa XI w dniu 24 grudnia 1930 r. Zwrócił się też z prośbą o materialne wsparcie dla wszystkich, którzy z przyczyn ekonomicznych pozbawieni zostali pracy ${ }^{12}$.

Następny list, spisany w dniu św. Leona 1932 r., poświęcony został sprawie wychowania chrześcijańskiego oraz ochronie dóbr religijnych i moralnych. Autor podkreślił w nim rolę rodziny w kształtowaniu właściwych postaw dzieci i młodzieży. Zwrócił też uwagę na zadania polskich szkół katolickich. Zachęcał także rodaków na obczyźnie do zrzeszania się w katolickich stowarzyszeniach ${ }^{13}$.

W dzień Matki Bożej Różańcowej 1932 r. rektor PMK wystosował do rodaków kolejny, czterostronicowy list, podnoszący tym razem rolę prasy katolickiej jako „siewcy i apostoła dobra” w opozycji do czasopism włączających się w nurt niszczenia w społeczeństwie pierwiastka religijnego i moralnego. Wskazując na informacyjną, wychowawczą oraz apostolską rolę prasy katolickiej, ks. Łagoda zachęcał wiernych do jej stałego czytelnictwa ${ }^{14}$.

Następnym dokumentem w omawianym zbiorze jest obszerne, jedenastostronicowe Orędzie Księdza Rektora o dziecku polskiem i wobec niego obowiazkach. List ten powstał w Paryżu, w Dniu Młodzianków, 28 grudnia 1932 r. W dołączonej do orędzia dyspozycji rektor polecał odczytanie go $\mathrm{z}$ ambony w drugą i trzecią

${ }^{10}$ APMKF, R.II. 4.1. „Okólniki”, List rektora PMK ks. Leona Łagody do Rodaków, mps.

${ }^{11}$ APMKF, R.II. 4.1. „Okólniki”, List księdza Rektora Leona Lagody do Rodaków z okazji 40-letniej rocznicy encykliki „Rerum Novarum”, mps.

12 APMKF, R.II. 4.1. „Okólniki”, List Ks. Rektora w sprawie bezrobocia, mps.

13 APMKF, R.II. 4.1. „Okólniki”, List rektora PMK ks. Leona Łagody do Rodaków, Paryż, w dzień św. Leona Papieża 1932, mps.

${ }^{14}$ APMKF, R.II. 4.1. „Okólniki”, List rektora PMK ks. Leona Łagody do Rodaków, Gniezno, w dzień Matki Boskiej Różańcowej 1932, mps. 
niedzielę stycznia 1933 r. Księża zatrudnieni w duszpasterstwie objazdowym mieli odczytać orędzie do 12 lutego 1933 r. $^{15}$

Dwanaście stron liczy kolejny list rektora PMK dotyczący apostolstwa ludzi świeckich. Miał on być przygotowaniem wiernych na przyjazd ks. biskupa częstochowskiego dra Teodora Kubiny, który przybywał zwizytować polskie parafie we Francji. Dokument wystosowany przez ks. Łagodę miał również być pobudką do spotęgowania aktywności religijnej zarówno w życiu wspólnot, jak i poszczególnych wiernych. List składał się z pięciu części i zakończenia. Na początku przedstawiona została aktualność apostolstwa ludzi świeckich. Następnie autor wskazał na potrzebę tegoż apostolstwa. Kolejno omówiona została istota apostolstwa świeckich, jego zadania i środki, jakich powinno się w ich realizacji używać. List przygotowany został przez ks. Łagodę w Paryżu w święto Wniebowstąpienia Pańskiego 25 maja 1933 r. ${ }^{16}$

Ostatni w omawianym zbiorze jest list rektora PMK do organizacji stowarzyszeń dzieci polskich we Francji, datowany na 23 sierpnia 1933 r. We wstępie ks. Łagoda przypomina wiernym o dwóch wielkich zlotach dzieci zrzeszonych w polskich organizacjach katolickich we Francji. Te wydarzenia zachęcają jednocześnie do rozwoju ruchu stowarzyszeniowego wśród dzieci i temuż właśnie służyć ma wzmiankowane pismo. W dalszej części listu autor omawia podstawy organizowania stowarzyszeń dzieci, cele tych zrzeszeń i obowiązki dorosłych wobec katolickich organizacji dziecięcych. W zakończeniu ks. Łagoda przywołał słowa kierowane do dzieci przez bpa T. Kubinę w czasie jego wizytacji polskich placówek duszpasterskich w Francji1 ${ }^{17}$.

\section{OKÓLNIKI REKTORA PMK, KS. LEONA ŁAGODY, Z LAT 1930-1932}

O ile przedstawione wyżej listy ks. Leona Lagody były sposobem jego komunikacji z wiernymi, o tyle okólniki adresowane były do duchowieństwa. Zgodnie z definicją miały charakter urzędowy i służyły dostarczeniu informacji, w tym również informacji o zarządzeniach, szerszemu gronu zainteresowanych ${ }^{18}$. Okólniki duszpasterskie miały pobudzać i koordynować działania duszpasterskie, informować o planach, inicjatywach i terminach, sygnalizować potrzeby duszpasterskie ${ }^{19}$.

15 APMKF, R.II. 4.1. „Okólniki”, Orędzie Księdza Rektora o dziecku Polskiem i wobec niego obowiązkach, w Paryżu, w dniu Młodzianków 28 grudnia 1932, mps.

${ }^{16}$ APMKF, R.II. 4.1. „Okólniki”, List Księdza Rektora o Apostolstwie Ludzi świeckich, w Paryżu, w święto Wniebowstąpienia Pańskiego 25 maja 1933, mps.

17 APMKF, R.II. 4.1. „Okólniki”, List Księdza Rektora o organizacji i stowarzyszeń dzieci polskich we Francji, Paryż, dnia 23 sierpnia 1933 r., mps.

18 Stownik języka polskiego, red. W. Doroszewski, t. V, Warszawa 1963, s. 932.

19 R. Sobański, Diecezja a wymagania nowego kodeksu. Uwagi o prawodawstwie (archi)diecezji katowickiej 1983-1993, „Śląskie Studia Historyczno-Teologiczne” 27/28 (1994-95), s. 40-42. 
W zachowanym zbiorze archiwalnym udało się odnaleźć 16 okólników ks. Leona Łagody z lat 1930-1933. Pierwszy z nich wydany został w Paryżu w marcu 1930 r. i nawiązywał do papieskiego orędzia z dnia 2 lutego 1930 r., dotyczącego prześladowania chrześcijan w Rosji bolszewickiej. We wzmiankowanym okólniku rektor PMK we Francji polecał, aby księża wygłosili do wiernych kazania na temat sytuacji chrześcijan w Rosji i skutków, jakie niesie ideologia bolszewicka. Kapłani mieli również odmówić z ludem litanię do Serca Jezusowego i odśpiewać suplikacje. Przedstawiciele organizacji katolickich mieli natomiast przesłać do Nuncjusza Apostolskiego w Warszawie dziękczynne adresy dla papieża za jego wystąpienie oraz prośbę do rządu polskiego o podjęcie na arenie międzynarodowej stosownych starań na rzecz poprawy sytuacji w Rosji ${ }^{20}$.

Kolejny okólnik, z marca 1931 r., dotyczył kryzysu ekonomicznego na świecie i szerzącego się bezrobocia. Rektor prosił, aby kapłani pouczyli rodaków o konieczności troski o utrzymanie miejsca pracy, przestrzegał również przed przyjazdem do Paryża w poszukiwaniu lepiej płatnego zajęcia ${ }^{21}$.

Do sytuacji socjalnej społeczeństwa i bezrobocia nawiązywał kolejny okólnik, który także datowany jest na marzec 1931 r. Rektor Łagoda zachęcał w nim do uroczystych obchodów 40-lecia encykliki Rerum Novarum papieża Leona XIII, podejmującej kwestie robotnicze. W celu uczczenia jubileuszu i twórcy tejże encykliki, polecał duchowieństwu odprawienie w maju uroczystego nabożeństwa z tej okazji, odczytanie listu do rodaków i zebranie składki na „katolicką akcję społeczną wśród wychodźstwa". Ponadto odbyć się powinny również obchody publiczne jubileuszu organizowane przez stowarzyszenia katolickie działające w koloniach polskich ${ }^{22}$.

W kwietniu 1931 r. rektor wystosował do kapłanów okólnik dotyczący opracowania kroniki polskich placówek duszpasterskich we Francji. Księża przekazać mieli do Rektoratu informacje o rozwoju organizacji duszpasterskiej, współpracy z duchowieństwem francuskim, działalności szkół polskich w koloniach i pracy nauczycielskiej, organizacji religijnych, społecznych i kulturalnych działających na obszarze placówki duszpasterskiej i ważnych wydarzeń z życia parafii ${ }^{23}$.

Istotne z punktu widzenia pracujących we Francji kapłanów były informacje przekazane w okólniku z dnia 1 lipca 1931 r., które dotyczyły organizacji egzaminów teologicznych: wikariuszowskich i proboszczowskich. W dokumencie przedrukowano pismo prymasa Polski ustanawiające komisję egzaminacyjną dla księży pracujących w duszpasterstwie emigracyjnym. Istotne było, że egzaminy zdane na obczyźnie

\footnotetext{
${ }^{20}$ APMKF, R.II. 4.1. „Okólniki”, Okólnik, [Paryż, w marcu 1930 r.], mps.

${ }^{21}$ APMKF, R.II. 4.1. „Okólniki”, Okólnik, [Paryż, w marcu 1931 r.], mps (1).

${ }^{22}$ APMKF, R.II. 4.1. „Okólniki”, Okólnik, [Paryż, w marcu 1931 r.], mps (2).

${ }^{23}$ APMKF, R.II. 4.1. „Okólniki”, Okólnik, [Paryż, w kwietniu 1931 r.], mps.
} 
miały być honorowane w kraju. W dalszej części pisma rektor podawał szczegółowe informacje na temat formy, tematów, terminów i przebiegu egzaminów ${ }^{24}$.

Także w lipcu 1931 r. wydany został Okólnik w sprawie organizowania dziatwy. Rektor zachęcał kapłanów do włączania dzieci do stowarzyszeń katolickich: Dzieciątka Jezus, misyjnych i innych działających na terenie placówki duszpasterskiej. Informacje o działalności takich organizacji kapłani przekazać mieli w formie sprawozdania do Rektoratu PMK. Do tegoż pisma ponownie dołączone zostały informacje o egzaminach wikariuszowskich i proboszczowskich przedstawione już wyżej25.

Kolejny zachowany okólnik datowany jest na grudzień 1931 r. Ksiądz Leon Łagoda poruszył w nim sprawę kazań o małżeństwie. W związku z nadużyciami przeciw świętości i nienaruszalności związku małżeńskiego rektor nakazywał wygłoszenie od niedzieli 10 stycznia 1932 r. cyklu kazań o małżeństwie chrześcijańskim, wskazywał również stosowną bibliografię, mającą pomóc w przygotowaniu tekstów homilii. Zarządził także, by w niedzielę 13 grudnia, pierwszą po święcie Niepokalanego Poczęcia NMP, odmówić lub odśpiewać antyfonę Pod Twoja obronę na intencję odwrócenia nieszczęścia zagrażającego Polsce w związku z projektowaną ustawą małżeńską ${ }^{26}$.

Okólnik z grudnia 1931 r. podejmował temat okresu adwentowego i przygotowań do świąt Bożego Narodzenia. W pierwszej części pisma rektor zwracał się do kapłanów z pasterskim słowem zachęty do wzajemnego umocnienia, pocieszenia i dodawania sobie nawzajem otuchy zakończonym życzeniami świątecznymi. Razem z tym pismem do kapłanów trafiły również opłatki i bożonarodzeniowe życzenia prymasa Polski, które rektor polecał odczytać wiernym w okresie świąt. Ksiądz Łagoda zarządził również intensywną akcję zbiórkową na rzecz bezrobotnych, chodziło zarówno o pomoc finansową, jak i rzeczową dla rodaków cierpiących nędzę na emigracji ${ }^{27}$.

Lektura okólników pozwala na stwierdzenie, że rektor PMK mocno zatroskany był o właściwą formację dzieci emigrantów. We wspomnianym już okólniku z lipca 1931 r., zachęcał do organizowania w ośrodkach duszpasterskich stowarzyszeń dzieci. W lutym 1932 r., w kolejnym piśmie okólnym przypomniał tę zachętę i in-

${ }^{24}$ APMKF, R.II. 4.1. „Okólniki”, Okólnik w sprawie egzaminów teologicznych, [Paryż, 1 lipca 1931 r.], mps.

${ }^{25}$ APMKF, R.II. 4.1. „Okólniki”, Okólnik w sprawie organizowania dziatwy, [Paryż, w lipcu 1931 r.], mps.

${ }^{26}$ APMKF, R.II. 4.1. „Okólniki”, Okólnik w sprawie kazań o małżeństwie, [Paryż, w grudniu 1931 r.], mps.

27 APMKF, R.II. 4.1. „Okólniki”, Okólnik w związku z tegorocznym okresem adwentowym, [Paryż, w grudniu 1931 r.], mps. 
formował duszpasterzy o tworzeniu związku stowarzyszeń, prosząc jednocześnie o wszelką pomoc dla ks. Paciorka i Makulca, odpowiedzialnych za zorganizowanie tegoż związku. Do okólnika dołączona była także informacja dotycząca zniżek kolejowych dla duchownych ${ }^{28}$.

W dzień Matki Bożej Gromnicznej 1932 r. rektor wystosował do podległego mu duchowieństwa okólnik o rekolekcjach kapłańskich. W pierwszej części pisma przypomniał ubiegłoroczne ćwiczenia rekolekcyjne. W podniosłym tonie pisał o pożądanych owocach tych rekolekcji, ubolewając nad niemożnością organizacji kolejnych spotkań. Polscy duszpasterze we Francji zostali w tym okólniku zobowiązani do odprawienia rekolekcji prywatnych i godzinnej prywatnej adoracji Najświętszego Sakramentu przynajmniej raz na kwartał ${ }^{29}$. Do swego pisma rektor PMK dołączył list ks. infułata Stanisława Krzeszkiewicza, rekolekcjonisty z Clamart, skierowany do polskich kapłanów ${ }^{30}$.

W marcu 1932 r. ks. Łagoda zachęcał kapłanów i wiernych świeckich do udziału w organizowanym w Dublinie w dniach 22-26 czerwca Międzynarodowym Kongresie Eucharystycznym. Informował duszpasterzy o możliwości udzielenia urlopu na czas pielgrzymki, zastrzegał jednak konieczność zorganizowania zastępstw, tak aby parafianie nie zostali całkowicie pozbawieni posługi religijnej w tym okresie ${ }^{31}$.

W okólnikach często pojawiały się tematy związane z wydarzeniami bieżącego życia społecznego. Zauważając nasiloną akcję ,zmierzającą do odcięcia świata od Chrystusowych źródeł prawdy, pokoju i szczęścia”, rektor Łagoda nakazywał w październiku 1932 r. rozwinięcie szerokich działań promujących prasę katolicką. Dniem szczególnym miało być święto Chrystusa Króla. W piśmie okólnym z dnia 14 października 1932 r. duszpasterze polscy we Francji zobowiązani zostali do odczytania listu apostolskiego o zadaniach prasy w niedzielę Chrystusa Króla (30 października) i urządzenia przed kościołami okolicznościowej wystawy dobrej książki i katolickiej prasy. Ponadto, na najbliższych zebraniach polskich stowarzyszeń, organizacji i bractw przeprowadzić mieli akcję propagandową dla polskiej prasy katolickiej ${ }^{32}$.

28 APMKF, R.II. 4.1. „Okólniki”, Okólnik w sprawie rejestracji katolickich stowarzyszeń polskich dzieci szkolnych, [Paryż, w lutym 1932 r.], mps.

29 APMKF, R.II. 4.1. „Okólniki”, Okólnik, [Paryż, w dzień Matki Boskiej Gromnicznej 1932r.], mps.

${ }^{30}$ APMKF, R II. 4.1. „Okólniki”, „Czcigodni i Drodzy konfratrzy”. List ks. Stanisława Krzeszkiewicza do kapłanów PMK we Francji, [b.m., b.d.], mps.

${ }^{31}$ APMKF, R.II. 4.1. „Okólniki”, Międzynarodowy Kongres Eucharystyczny w Dublinie, [Paryż, w marcu 1932 r.], mps.

32 APMKF, R.II. 4.1. „Okólniki”, Okólnik w sprawie akcji prasowej w święto Chrystusa Króla, [Paryż, dnia 14 października 1932 r.], mps. 
Także w październiku 1932 r. do kapłanów PMK rozesłane zostało pismo okólne dotyczące poświęcenia pomnika Najświętszego Serca Jezusowego w Poznaniu. Ksiądz Łagoda polecał w nim wygłoszenie w niedzielę 23 października stosownego kazania o Sercu Jezusowym, zaś w niedzielę 30 października duszpasterze mieli wraz z wiernymi odmówić litanię do Serca Jezusowego wraz z ofiarowaniem rodzaju ludzkiego temuż Sercu Jezusowemu. Rektor zachęcał również do wystawienia Najświętszego Sakramentu wszędzie tam, gdzie przepisy i warunki będą na to pozwalały. Do wzmiankowanego okólnika dołączone było pismo Komitetu Budowy Pomnika Najświętszego Serca Pana Jezusa w Poznaniu ${ }^{33}$.

Na dzień 19 kwietnia 1933 r. datowany jest krótki okólnik odnoszący się do urlopów wakacyjnych. Rektor przypominał w nim rozporządzenie dotyczące urlopów z marca 1931 r. i polecił zgłaszanie stosownych wniosków o wyznaczanie zastępstwa najpóźniej do końca maja $1933 \mathrm{r}^{34}$

W maju 1933 r. duszpasterze PMK otrzymali pismo okólne dotyczące konieczności odczytania wiernym listu o apostolstwie świeckich, który to list został dołączony do okólnika. List należało odczytać, wraz z objaśnieniami, w poszczególne niedziele czerwca, począwszy od niedzieli Trójcy Przenajświętszej. Jednocześnie rektor przestrzegał przed wprowadzaniem do objaśnień elementów polityki ${ }^{35}$.

Zbiór okólników rektora PMK z lat 1930-1933 zamyka pismo okólne dotyczące listu o stowarzyszeniach dzieci polskich. Rektor PMK poleca odczytać wiernym wzmiankowany list w czasie nabożeństw polskich w pierwszą i drugą niedzielę września wraz ze stosownymi objaśnieniami poruszanych w piśmie kwestii. W tym okólniku znalazło się też polecenie przygotowania statystyk co do ruchu organizacyjnego wśród dzieci w obrębie placówki duszpasterskiej. Księża mieli dokładnie określić liczbę stowarzyszonych dzieci i abonentów „Młodego Polaka” ${ }^{\text {”36. }}$

\section{PISMA RÓŻNE}

W zbiorze okólników sygnowanym datami 1929-1933 znajdują się również inne pisma. W ich tytułach nie pojawiły się słowa „list” lub „okólnik”, dlatego też omówione zostaną osobno.

${ }^{33}$ APMKF, R.II. 4.1. „Okólniki”, Okólnik w sprawie poświęcenia pomnika Najśw. Serca Jezusowego w Poznaniu, [Paryż, w październiku 1932 r.], mps.

${ }^{34}$ APMKF, R.II. 4.1. „Okólniki”, Okólnik [dotyczący urlopów wakacyjnych], [Paryż, dnia 19 kwietnia 1933 r.], mps.

${ }^{35}$ APMKF, R.II. 4.1. „Okólniki”, Okólnik [dotyczący listu o apostolstwie świeckich], [Paryż, w maju 1933 r.], mps.

${ }^{36}$ APMKF, R.II. 4.1. „Okólniki”, Okólnik, [Paryż, dnia 23 sierpnia 1933 r.], mps. 
Pierwsze takie pismo datowane jest na sierpień 1930 r. Dotyczyło ono organizacji jubileuszu Prymasa Polski, ks. kardynała Augusta Hlonda. Kapłani zostali w tym dokumencie zobowiązani do odczytania listu ks. rektora do rodaków w dniu 21 września, odprawienia uroczystego nabożeństwa w jedną z niedziel od 28 września do końca października i wygłoszenia wówczas kazania o kapłaństwie, zorganizowania wieczornicy urozmaiconej deklamacjami i występami chóru. Ponadto, należało również przesłać telegramy hołdownicze z życzeniami dla prymasa i zorganizować zbiórkę pieniężną na cel budowy seminarium dla duszpasterstwa zagranicznego. Rektor informował również o rozprowadzaniu wśród wiernych pocztówki z podobizną prymasa i przygotowywaniu albumu o działalności polskiego duszpasterstwa we Francji. Zadaniem księży było dostarczenie informacji oraz zdjęć ilustrujących tę działalnośćc ${ }^{37}$.

W październiku 1930 r. w rozesłanym do duszpasterzy piśmie rektor prosił o odczytanie listu do wiernych dotyczącego wspólnych dla całego duchowieństwa polskiego we Francji rekolekcji. Kapłani mieli również zawierzyć Sercu Jezusowemu ojczyznę, polskie duchowieństwo i wiernych we Francji. Do pisma dołączony był wspomniany list do wiernych ${ }^{38}$.

Kolejny dokument zachowany w omawianym zasobie to program zjazdu duchowieństwa polskiego we Francji w dniach 20-21 listopada 1930 r. Podano w nim nazwiska referentów i podejmowaną przez nich tematykę oraz godzinowy plan spotkania ${ }^{39}$.

We wrześniu 1931 r. rektor w przesłanym piśmie propagował Dzieło Apostolstwa Chorych, przedstawiając genezę jego powstania w Polsce i formy działalności. Rektor zachęcał duszpasterzy polskich we Francji do zapoznania się z ideą Dzieła i podjęcia wespół z członkami organizacji katolickich działających w parafiach starań o zapisanie chorych na członków tegoż Dzieła ${ }^{40}$.

W maju 1932 r. rektor wystosował do bliżej nieokreślonych adresatów (,Szanowna/y/ Pani/e/”) pismo w sprawie katechizmu dla dzieci emigrantów napisanego przez ks. dr. Aleksandra Syskiego. Do pisma dołączony został okazowy egzemplarz katechizmu, który zdaniem ks. Łagody winien być wprowadzony jako jednolity podręcznik nauki religii dla dzieci polskich na terenie Francji ${ }^{41}$.

${ }^{37}$ APMKF, R.II. 4.1. „Okólniki”, [Pismo rektora PMK], [Paryż, w sierpniu 1930 r.], mps.

38 APMKF, R.II. 4.1. „Okólniki”, [Pismo rektora PMK], [Paryż, w sierpniu 1930 r.], [Paryż, w październiku 1930 r.], mps.

${ }^{39}$ APMKF, R.II. 4.1. „Okólniki”, Program zjazdu duchowieństwa polskiego we Francji, mps.

${ }^{40}$ APMKF, R.II. 4.1. „Okólniki”, Dzieło Apostolstwa Chorych [Paryż, we wrześniu 1931 r.], mps.

${ }^{41}$ APMKF, R.II. 4.1. „Okólniki”, [Pismo rektora PMK], [Paryż, w maju 1932 r.], mps (1). 
Podobną formę ma kolejne pismo rektora Łagody, także wystosowane do bliżej nieokreślonych adresatów. Kapłan zachęcał w nim do lektury encykliki papieża Piusa XI o wychowaniu chrześcijańskim. Do pisma dołączony był gratisowy egzemplarz wzmiankowanej encykliki. Uważna lektura obu pism pozwala domniemywać, że kierowane one były do polskiego nauczycielstwa pracującego w szkołach na terenie działania Polskiej Misji Katolickiej we Francji ${ }^{42}$.

W roku 1932 rektor PMK wystosował także pismo adresowane „Do Wielebnego Duchowieństwa i Wiernych”, a dotyczące obchodów dziesięciolecia intronizacji papieskiej Piusa XI. Pismo to pozbawione jest datacji, lecz podnoszone w nim kwestie przygotowania uroczystego obchodu tej rocznicy pozwalają sytuować powstanie dokumentu przed 14 lutego 1932 r. W pierwszej części swego pisma rektor przywoływał osobę i zasługi Piusa XI w prowadzeniu Kościoła katolickiego. Kolejno zachęcał wiernych do oddania hołdu papieżowi i modlitwy w jego intencji. Trzecia część pisma to wskazania dla kapłanów, jak należy urządzić uroczysty obchód ku czci Piusa XI:

1/ odmówi Wielebne duchowieństwo z wiernymi w niedzielę 14 lutego na głównych nabożeństwach polskich, litanię do Serca Jezusowego z ofiarowaniem całego rodzaju ludzkiego Najśw. Sercu Jezusowemu i odśpiewa Te Deum z modlitwą dziękczynną. 2/ zachęcam gorąco wszystkie bractwa, towarzystwa kościelne i stowarzyszenia katolickie, żeby na swoich zebraniach w miesiącach lutym albo marcu uczciły pamięć ojca świętego Piusa XI. 3/zapraszam wszystkie związki, organizacje i stowarzyszenia stojące na gruncie katolickim, żeby uchwaliły adresy hołdownicze dla papieża Piusa $\mathrm{XI}^{43}$.

Na dzień 13 marca 1933 r. datowane jest pismo kierowane do duszpasterzy PMK we Francji, a dotyczące listu pasterskiego ks. prymasa kard. A. Hlonda $O \dot{z} y-$ ciu parafjalnem. Choć dokument ten dotyczył przede wszystkim warunków życia parafialnego w kraju, to jednak przebywający wówczas w Gnieźnie rektor Łagoda uznał, że powinien on trafić do duszpasterzy polskich we Francji. Także tu miał służyć odnowieniu życia wspólnotowego parafian. Ksiądz Łagoda zlecał podległym sobie księżom zapoznanie się z tym dokumentem oraz odczytanie odpowiednio dobranych fragmentów $\mathrm{z}$ ambony wraz z odpowiednim ich objaśnieniem ${ }^{44}$.

W dniu 8 kwietnia 1933 r. rektor PMK wystosował do kapłanów pismo dotyczące praktyk neomaltuzjańskich i postaw duszpasterza i spowiednika wobec

${ }^{42}$ APMKF, R.II. 4.1. „Okólniki”, [Pismo rektora PMK], [Paryż, w maju 1932 r.], mps (2).

${ }^{43}$ APMKF, R.II. 4.1. „Okólniki”, Pismo ks. Leona Łagody Rektora Polskiej Misji Katolickiej we Francji do Wielebnego Duchowieństwa i Wiernych, [1932], mps.

${ }^{44}$ APMKF, R. II.4.1. „Okólniki”, Pismo ks. Leona Łagody do księży, Gniezno, dnia 13 marca 1933 r., mps. 
nich. Przywołując badania Japończyka K. Ogino i Austriaka H. Knausa dotyczące okresowej wstrzemięźliwości małżeńskiej (metoda kalendarzyka małżeńskiego), zalecał duszpasterzom zapoznanie się z artykułami z czasopism teologicznych ze szczególnym uwzględnieniem „Ateneum Kapłańskiego”. Rektor określił również w omawianym piśmie obowiązki spowiedników względem małżonków i grzechów dotyczących pożycia małżeńskiego $0^{45}$.

Ten dokument jest ostatnim w omawianym zbiorze.

\section{BIBLIOGRAFIA}

\section{Archiwalia}

Archiwum Polskiej Misji Katolickiej we Francji

R.II. 4.1. „Okólniki”

„Czcigodni i Drodzy konfratrzy”. List ks. Stanisława Krzeszkiewicza do kapłanów PMK we Francji, [b.m., b.d.], mps.

Duszpasterz i spowiednik wobec praktyk neomaltuzjańskich. Pismo ks. Leona Łagody do księży, Paryż, dnia 8 kwietnia 1933 r., mps.

Dzieło Apostolstwa Chorych [Paryż, we wrześniu 1931 r.], mps.

List Ks. Rektora w sprawie bezrobocia, mps.

List księdza Rektora Leona Łagody do Rodaków z okazji 40-letniej rocznicy encykliki „Rerum Novarum”, mps.

List Księdza Rektora o Apostolstwie Ludzi świeckich, w Paryżu, w święto Wniebowstąpienia Pańskiego 25 maja 1933, mps.

List Księdza Rektora o organizacji i stowarzyszeń dzieci polskich we Francji, Paryż, dnia 23 sierpnia 1933 r., mps.

List rektora PMK ks. Leona Łagody do młodzieży z 1929 na uroczystość św. Stanisława Kostki, mps.

List rektora PMK ks. Leona Łagody do Rodaków z dnia 8 maja 1929 r., mps.

List rektora PMK ks. Leona Łagody do Rodaków, Paryż, w dzień św. Leona Papieża 1932, mps.

List rektora PMK ks. Leona Łagody do Rodaków, Gniezno, w dzień Matki Boskiej Różańcowej 1932, mps.

List rektora PMK ks. Leona Łagody do Rodaków, mps.

List rektora PMK ks. Leona Łagody do Rodaków, Paryż, w dniu Matki Boskiej Częstochowskiej 1930, mps.

Międzynarodowy Kongres Eucharystyczny w Dublinie, [Paryż, w marcu 1932 r.], mps.

Okólnik, [Paryż, dnia 23 sierpnia 1933 r.], mps.

Okólnik [dotyczący listu o apostolstwie świeckich], [Paryż, w maju 1933 r.], mps.

${ }^{45}$ APMKF, R. II.4.1. „Okólniki”, Duszpasterz i spowiednik wobec praktyk neomaltuzjańskich.

Pismo ks. Leona Łagody do księży, Paryż, dnia 8 kwietnia 1933 r., mps. 
Okólnik [dotyczący urlopów wakacyjnych], [Paryż, dnia 19 kwietnia 1933 r.], mps.

Okólnik w sprawie akcji prasowej w święto Chrystusa Króla, [Paryż, dnia 14 października 1932 r.], mps.

Okólnik w sprawie egzaminów teologicznych, [Paryż, 1 lipca 1931 r.], mps.

Okólnik w sprawie kazań o małżeństwie, [Paryż, w grudniu 1931 r.], mps.

Okólnik w sprawie organizowania dziatwy, [Paryż, w lipcu 1931 r.], mps.

Okólnik w sprawie poświęcenia pomnika Najśw. Sera Jezusowego w Poznaniu, [Paryż, w październiku 1932 r.], mps.

Okólnik w sprawie rejestracji katolickich stowarzyszeń polskich dzieci szkolnych, [Paryż, w lutym 1932 r.], mps.

Okólnik związku z tegorocznym okresem adwentowym, [Paryż, w grudniu 1931 r.], mps.

Okólnik, [Paryż, w dzień Matki Boskiej Gromnicznej 1932r.], mps.

Okólnik, [Paryż, w kwietniu 1931 r.], mps.

Okólnik, [Paryż, w marcu 1930 r.], mps.

Okólnik, [Paryż, w marcu 1931 r.], mps (2).

Okólnik, [Paryż, w marcu 1931 r.], mps (1).

Orędzie Księdza Rektora o dziecku Polskiem i wobec niego obowiązkach, w Paryżu, w dniu Młodzianków 28 grudnia 1932, mps.

Pismo ks. Leona Łagody do księży, Gniezno, dnia 13 marca 1933 r., mps.

Pismo ks. Leona Lagody Rektora Polskiej Misji Katolickiej we Francji do Wielebnego Duchowieństwa i Wiernych, [1932], mps.

[Pismo rektora PMK], [Paryż, w maju 1932 r.], mps (1).

[Pismo rektora PMK], [Paryż, w maju 1932 r.], mps (2).

[Pismo rektora PMK], [Paryż, w sierpniu 1930 r.], [Paryż, w październiku 1930 r.], mps.

[Pismo rektora PMK], [Paryż, w sierpniu 1930 r.], mps.

Program zjazdu duchowieństwa polskiego we Francji, mps.

Słowo do Rodziców z okazji zbliżającej się uroczystości świętego Stanisława Kostki, październik 1929 r., mps.

\section{Opracowania}

Brudzisz M., Archiwum Polskiej Misji Katolickiej we Francji, Kraków-Lublin: Homo Dei 2015.

Słownik języka polskiego, red. W. Doroszewski, t. V, Warszawa: PWN 1963.

Dzwonkowski R., Polska opieka religijna we Francji 1909-1939, Poznań-Warszawa: Pallottinum 1988.

DUCHNIEWSKI J., Listy pasterskie, w: Encyklopedia Katolicka, t. X, Lublin: TN KUL 2004, kol. 1161-1165.

SoBAŃski R., Diecezja a wymagania nowego kodeksu. Uwagi o prawodawstwie (archi)diecezji katowickiej 1983-1993, „Śląskie Studia Historyczno-Teologiczne” 27/28 (199495), s. 25-46.

SzYMAŃSKi J., Duszpasterze Polonii i Polaków za granicą. Słownik biograficzny, t. II, Lublin: Miejska i Powiatowa Biblioteka Publiczna 2011. 


\section{LISTY PASTERSKIE, OKÓLNIKI I INNE PISMA \\ REKTORA POLSKIEJ MISJI KATOLICKIEJ, KS. LEONA ŁAGODY, W ZBIORACH ARCHIWUM PMK W PARYŻU}

\section{Streszczenie}

Celem artykułu jest przedstawienie działalności Polskiej Misji Katolickiej we Francji na przykładzie pism jej rektora ks. Leona Łagody. Autor dokonuje analizy zawartości tego zbioru, odnoszącego się głównie do lat 1929-1933, a który rzuca światło na aktywność duszpasterską i organizacyjną władz Polskiej Misji Katolickiej we Francji. Dokonuje wyraźnego rozróżnienia na listy, które rektor ks. Leon Łagoda kierował do wiernych, i okólniki, które były tekstami urzędowymi przeznaczonymi dla duchowieństwa. Osobną kategorię stanowią pisma adresowane np. do hierarchów kościelnych lub związane z obchodami uroczystości.

Słowa kluczowe: Polska Misja Katolicka we Francji; rektor PMK; listy pasterskie; okólniki

\section{PASTORAL LETTERS, CIRCULARS AND OTHER WRITINGS OF THE RECTOR OF THE POLISH CATHOLIC MISSION, FR. LEON ŁAGODA, IN THE ARCHIVES OF THE POLISH CATHOLIC MISSION IN PARIS}

The aim of the article is to present the activity of the Polish Catholic Mission in France on the example of letters written by its rector, Fr. Leon Lagoda. The author analyses the content of this collection, referring mainly to the years 1929-1933. The collection sheds light on the pastoral and organisational activity of the Polish Catholic Mission in France. The author makes a clear distinction between the letters which Rector Leon Lagoda addressed to the faithful and the circulars, which were official texts intended for the clergy. A separate category constitutes letters addressed, for instance, to church hierarchs or those related to different celebrations.

Keywords: Polish Catholic Mission in France; Rector of Polish Catholic Mission; pastoral letters; circulars 